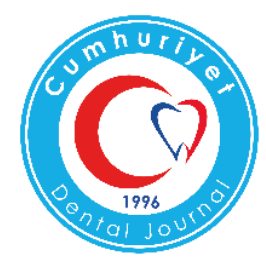

\title{
A COMPARISON OF THE WATER ABSORPTION AND WATER SOLUBILITY VALUES OF FOUR DIFFERENT COMPOSITE RESIN MATERIALS
}

\author{
Dört Farklı Kompozit Materyalinin Su Emilim ve Çözünürlük Değerlerinin \\ Karşılaş̧ırılması
}

\author{
Suzan CANGÜL ${ }^{1}$, Özkan ADIGÜZEL ${ }^{2}$, Samet TEKİN ${ }^{3}$, \\ Faruk ÖZTEKIN ${ }^{4}$, Ömer SATICI ${ }^{5}$
}

\begin{abstract}
Makale Kodu/Article Code : :449340
Makale Gönderilme Tarihi $\quad$ : 31.07.2018

Kabul Tarihi

: 10.12 .2018
\end{abstract}

\section{ABSTRACT}

Objectives: The aim of this study was to compare the water absorption and water solubility of four different composte resin materials.

Materials and Methods: A total of 40 cylindrical discs were prepared and polymerised with light, as 10 from each group, each sample $2 \mathrm{~mm}$ in depth and $8 \mathrm{~mm}$ in diameter. The samples were kept for $24 \mathrm{hrs}$ in a dessicator until a stable weight was reached. Then, the weight of each sample was measured on highly sensitive scales. To calculate the water absorption and solubility, measurements were made again with the sensitive scales at the end of 1, 7 and 30 days. The data obtained were evaluated with One-Way ANOVA variance analysis and the Friedman test.

Results: As a result of the statistical analyses, significant differences were determined between the composite resins in respect of water absorption on days 7 and 30 and in respect of solubility on day 30 only $(\mathrm{p}<0.05)$.

Conclusion: When the water absorption and water solubility of composite resins at the end of 30 days were evaluated statistically, it was observed that Ceram X One material showed the lowest values. This is related to the structure of the restorative material.

It can be concluded that the negative mechanical, physical and biological effects created by the water absorption and water solubility factors of restorative materials are important issues that should be taken into consideration.

Key Words: Composite resin, water absorption, water solubility.

\section{ÖZET}

Amaç: Bu çalışmanın amacı estetik amaçlı kullanılan dört farklı kompozit rezinin su emilimi ve sudaki çözünürlüklerinin karşılaştırılmasıdır.

Gereç ve Yöntemler: Çalışmada her kompozit grubundan 10 tane olmak üzere $2 \mathrm{~mm}$ derinliğinde $8 \mathrm{~mm}$ çapında toplam 40 adet silindirik disk hazırlandı ve 1şıkla polimerize edildi. Örnekler sabit ağırlıklarına ulaşıncaya kadar $24 \mathrm{~h}$ desikator icinde bekletildi. Daha sonra tüm örneklerin ağırlıkları hassas terazi ile ölçüldü. 1,7 ve 30 . günlerin sonunda su emilimini ve çözünürlük sonuçlarını hesaplamak için hassas terazi ile tartımlar yapıldı. Elde edilen veriler ANOVA tek yönlü varyans analizi ve Friedman testleri kullanılarak değerlendirildi.

Bulgular: Yapılan istatistikler sonucunda kompozit rezinlerin su emiliminde 7 . ve 30 . günlerde, sudaki çözünürlüklerinde ise sadece 30 . günde anlamlı farklılıkların olduğu saptanmıştır $(\mathrm{p}<0,05)$.

Sonuç: Kompozit rezinlerin 30 gün sonundaki su emilimi ve suda çözünürlüğü istatistiksel açıdan değerlendirildiğinde Ceram X One materyalinin en düşük değerleri gösterdiği görülmüştür. $\mathrm{Bu}$ da restoratif materyalin yapısı ile ilişkilidir.

Sonuç olarak restoratif materyallerin su emilimi ve suda çözünürlük faktörleri, mekanik, fiziksel ve biyolojik olarak olumsuz etkiler oluşturduğundan gözönünde bulundurulması gereken önemli konulardandır.

Anahtar kelimeler: Kompozit rezin, su emilimi, sudaki çözünürlük

\footnotetext{
${ }^{1}$ Dicle University Faculty Of Dentistry, Department Of Restorative Dentistry, Diyarbakir/Turkey

${ }^{2}$ Dicle University, Faculty Of Dentistry, Department Of Endodontics, Diyarbakir/Turkey

${ }^{3}$ Firat University Faculty Of Dentistry, Department Of Prosthodontics, Elâzı ̆ /Turkey

${ }^{4}$ Frrat University Faculty Of Dentistry, Department Of Endodontics, Elâzı ğ /Turkey

${ }^{5}$ Dicle University Faculty Of Medical, Department Of Biostatistics And Medical Informatics, Diyarbakir/Turkey
} 


\section{INTRODUCTION}

Advances in adhesive dentistry have made it significantly easier for dentists to select the correct materials for clinical use. Restorative materials in combination with adhesive resins aiming to meet the aesthetic expectations of the patient, are frequently used especially in the restoration of dental caries, congenital defects, dental wear and crown fractures. ${ }^{1}$

Composite materials, which are currently widely used in aesthetic dentistry, were first developed by Dr R. Bowen in 1962. These materials, which were produced as an alternative to amalgam, have the advantages of strong adhesion to dental tissues, superior physical properties, can be easily shaped and have a broad colour scale, and there has been increasing use of these materials in the posterior region. $^{2}$

However, in adition to these properties, there are several disadvantages that can affect the clinical life of composite resins, such as surface smoothness, microleakage, polymerisation freezing, fragility, discolouration, water absorption, wear, and low resistance to contraction and tension. ${ }^{3,4}$

A disadvantage of all composite resins is the water absorption property and that hydroscopic expansion occurs associated with water absorption within the mouth. ${ }^{5,6}$ The water absorption and solubility of restorations are extremely important because composite resin-based filling materials in the interface region are usually in contact with the gingival region and fluid in the gingival groove. ${ }^{7}$ As a result of this, fractures and discolourations are observed in the interface contours of composite resin restorations.

According to several studies, water absorption of restorative materials deteriorates the chemical structures and this is seen with an increase in surface smoothness of the materials. $^{8}$
Increased weight related to water absorption and subsequent water solubility of the material (filling and monomers) occurs through two different mechanisms. ${ }^{9}$ The water solubility factor that causes a change in the biological structures of restorations causes aesthetic loss and impairment of the marginal and surface properties. ${ }^{10}$

The type and volume of small parts of fillers in the structure of composite resins have an effect on water absorption and solubility. ${ }^{11,12}$ With an increase in the amount of filler in the resin content, the water absorption and solubility decreases. In a study by $\mathrm{Li}^{13}$ that investgated the effect of filler content on the resin structure, it was found that the water absorption values of composite resins with a high percentage of filler content were significantly lower than those of resins with a low filler content.

Ortengren et $a l .{ }^{14}$ reported that the deterioration of wear and mechanical properties in composite resins was associated with the dampness in the oral environment. This dampness created erosions and deteriorations in the resins as a result of hydrolysis and enzymatic hydrolysis reactions.

The aim of this study was to compare the water absorption and water solubility values of four different composite resins used for aesthetic purposes.

\section{MATERIAL and METHODS}

\section{Preparation of the Samples}

The aim of this study was to compare the changes in the water absorption and solubility values of four different composite resins over the period of one month (Table 1). 
Table 1: The components of the composite types and the manufacturers

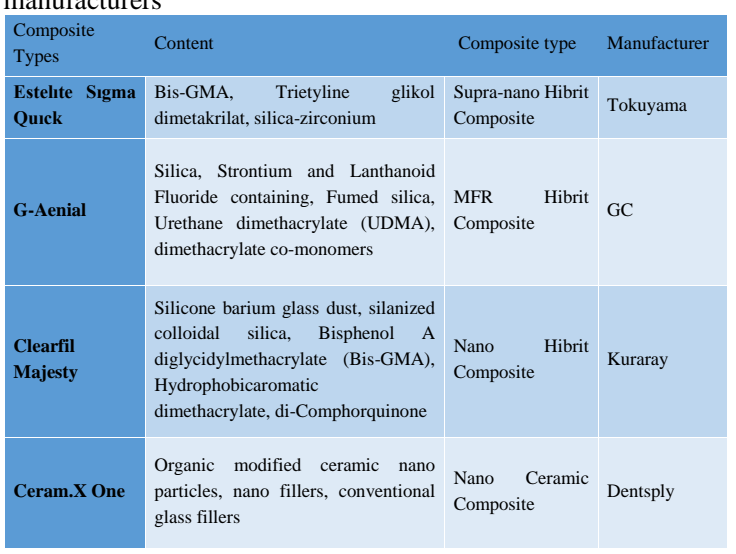

A total of 40 plastic cylindrical discs were prepared as 10 from each composite group, each sample $2 \mathrm{~mm}$ in depth and $8 \mathrm{~mm}$ in diameter. The restorative materials tested were G-Aenial GC Corporation, Tokyo, Japan), Estelite Sigma Quick (Tokuyama, Tokyo, Japan), Ceram X One (Dentsply, DeTrey, Konstanz, Germany) and Clearfil Majesty (Kuraray Medical, Okoyama, Japan). Using an oral spatula, each material was placed on the cylindrical discs prepared at equal sizes. To provide a smoth surface, pressure with cement glass was applied over a clear band. Then an LED light source (Guilin Woodpecker, China, $1100 \mathrm{~mW} / \mathrm{cm}^{2}$ ) was applied over the glasss for 20 secs, and after removing the glass and clear band, the light was applied again for 20 secs and polymerisation of the composites was achieved. All the samples were then polished with Soflex discs (3M ESPE, St. Paul, MN, USA).

\section{Water Absorption and Solubility Test}

All the samples were placed in glass bottles in the relevant groups of 10 for each material. The

ISO 4049:199416 test was used for this experiment. For the samples to reach a stable weight, they were kept in a dessicator at $37 \pm 1^{\circ} \mathrm{C}$ for 24 hours. Then all the samples were weighed on scales sensitive to 10 micrograms (Chyo JL180, Chyo Balance Corp, Japan) and the weights were recorded as M1. After completion of the first measurements, the samples were placed in distilled water at $37 \pm 1^{\circ} \mathrm{C}$ and left in an incubator for 24 hours, after which they were removed, dried with drying papers and weighed again with these second values recorded as M2a.

At the end of the 1st day, for the materials to regain a stable weight, the samples were again left in the dessicator for 24 hours. At the end of this period, the samples were measured again and recorded as M3. All the samples were then left in distilled water in an incubator for 7 days, after which they were removed, dried and weighed again (M2b). The same procedures were repeated at the end of 30 days and the values measured were recorded as M2c.

M1: The initial weights of the samples after removal from the desiccator (in $\mu \mathrm{g}$ )

M2: The weights of the samples after 1 day in distilled water after desiccator (M2a)

M2b: The weights of the samples after standing in distilled water for 7 days (in $\mu \mathrm{g}$ )

M2c: The weights of the samples after 30 days in distilled water (in $\mu \mathrm{g}$ )

M3a: The weights of the specimens after they were placed in the desiccator for the second time (in $\mu \mathrm{g}$ )

M3b: Weight of samples after second time desiccation (in $\mu \mathrm{g}$ )

\section{Water absorption $(\mu \mathrm{g} / \mathrm{mm} 3)=$}

$\underline{\mathrm{M} 2}(\mathrm{a}, \mathrm{b}, \mathrm{c})(\mu \mathrm{g})-\mathrm{M} 3(\mathrm{a}, \mathrm{b})(\mu \mathrm{g})$

$$
\mathrm{V}(\mathrm{mm} 3)
$$

Water solubility $(\mu \mathrm{g} / \mathrm{mm} 3)=$

$$
\frac{\operatorname{M1}(\mu \mathrm{g})-\mathrm{M} 3(\mathrm{a}, \mathrm{b})(\mu \mathrm{g})}{\mathrm{V}(\mathrm{mm} 3)}
$$

\section{RESULTS}

In the statistical evaluation of the water absorption of the composite resins, Anova One-Way Variance analysis and the Friedman test were used. No statistically significant 
difference was determined between the resins in respect of the water absorption values on Day 1 (Table 2). ( $\mathrm{F}=2.625 \mathrm{P}=0.065$, Kruskal Wallis Chi-Square $=5.97 \mathrm{P}=0.11 \mathrm{NS}$ ).

\section{Anova One-Way Variance Analysis}

In the comparison of the water absorption values of the resins according to the days, the Friedman test was used. The difference between the water absorption levels on Day 7 $(\mathrm{F}=11.051 \mathrm{P}=0.000)$ and Day $30(\mathrm{~F}=25.476$ $\mathrm{P}=0.000$ ) was determined to be statistically significant for the Clearfil Majesty, Estelite Sigma Quick, G-Aenial and Ceram X One composites. (Table 2)

Table 2. A comparison of the water absorption values of four different composite resin materials on Day 1, 7 and 30.

\begin{tabular}{|c|c|c|c|c|c|c|}
\hline & & & $\mathbf{N}$ & Mean & Std. Deviation & $\mathbf{P}$ \\
\hline \multirow{6}{*}{ DAY 1} & \multicolumn{2}{|c|}{ CLEARFIL MAJESTY } & 10 & ,00000686 &, 000003938 & \multirow{4}{*}{$\mathrm{p}=0.065$} \\
\hline & \multicolumn{2}{|c|}{$\begin{array}{l}\text { ESTELITE SIGMA } \\
\text { QUICK }\end{array}$} & 10 & ,00000448 & ,000001075 & \\
\hline & \multicolumn{2}{|c|}{ G-AENIAL } & 10 & , 00000607 & ,000004182 & \\
\hline & \multicolumn{2}{|c|}{ CERAM X ONE } & 10 & ,00000328 & ,000002253 & \\
\hline & \multicolumn{2}{|l|}{ Total } & 40 & ,00000517 &, 000003322 & \\
\hline & Model & $\begin{array}{l}\text { Fixed } \\
\text { Effects }\end{array}$ & & & ,000003132 & \\
\hline \multirow{6}{*}{ DAY 7} & \multicolumn{2}{|c|}{ CLEARFIL MAJESTY } & 10 & 00001094 & ,000002735 & \multirow{4}{*}{$\mathrm{p}=0.000$} \\
\hline & \multicolumn{2}{|c|}{$\begin{array}{l}\text { ESTELITE SIGMA } \\
\text { QUICK }\end{array}$} & 10 & ,00000975 &, 000002240 & \\
\hline & \multicolumn{2}{|c|}{ G-AENIAL } & 10 & ,00001472 & ,000002963 & \\
\hline & \multicolumn{2}{|c|}{ CERAM X ONE } & 10 & ,00000826 &, 000002528 & \\
\hline & \multicolumn{2}{|l|}{ Total } & 40 & ,00001092 & ,000003502 & \\
\hline & Model & $\begin{array}{l}\text { Fixed } \\
\text { Effects }\end{array}$ & & , 000002630 & ,00000 & \\
\hline \multirow{6}{*}{ DAY 30} & CLEA & L MAJESTY & 10 & ,00001114 & ,000002922 & \multirow{3}{*}{$\mathrm{p}=0.000$} \\
\hline & \multicolumn{2}{|c|}{$\begin{array}{l}\text { ESTELITE SIGMA } \\
\text { QUICK }\end{array}$} & 10 & 00000806 & ,000003092 & \\
\hline & \multicolumn{2}{|c|}{ G-AENIAL } & 10 & ,00001502 & ,000001280 & \\
\hline & \multicolumn{2}{|c|}{ CERAM X ONE } & 10 & ,00000567 & ,000002439 & \\
\hline & \multicolumn{2}{|l|}{ Total } & 40 & ,00000997 & ,000004302 & \\
\hline & Model & $\begin{array}{l}\text { Fixed } \\
\text { Effects }\end{array}$ & & ,000002534 & ,00000 & \\
\hline
\end{tabular}

On Days 7 and 30 the lowest water absorption values were determined in the Ceram X One group, and the highest values in the Clearfil Majesty composite samples (Figure 1). In the comparison of the water solubility values of the composite resins on Days 1,7 and 30 a statistically significantly difference was determined only on Day 30 (Table 3).

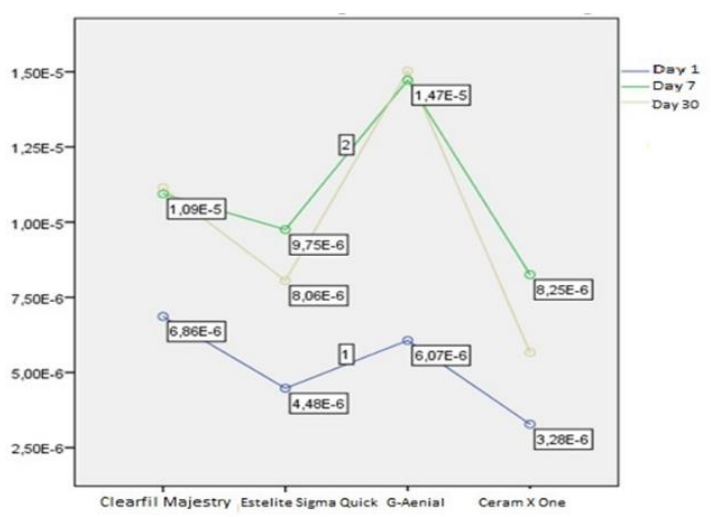

Figure 1. Changes in the water absorption values of the composite resins on Days 1, 7 and 30.

Table 3. The comparison of the water solubility values of the composite resins on Days 1, 7 and 30.

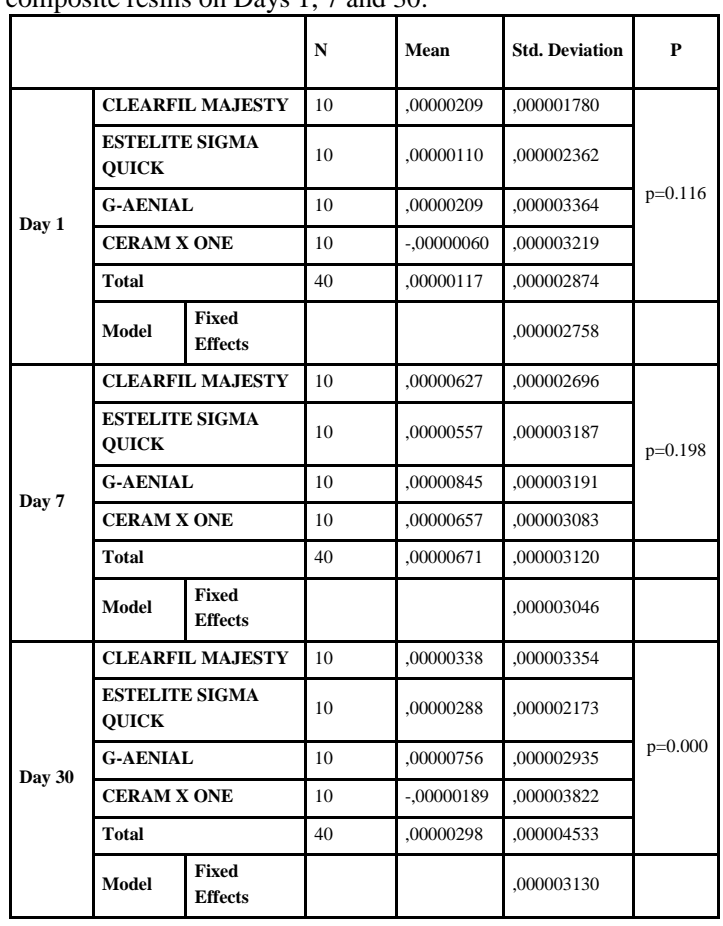

On the 30th day, the differences between the composite resins (Ceram X One, Clearfil Majesty, G-Aenial and Estelite Sigma Quick) in terms of water solubility were found to be statistically significant $(\mathrm{p}<0.05)$.

In the evaluation of the water solubility values on Day $30(\mathrm{~F}=15.262 \mathrm{P}=0.000)$ the highest values were determined in G-Aenial composite and the lowest values in the Ceram $\mathrm{X}$ One composite samples (Figure 2). 


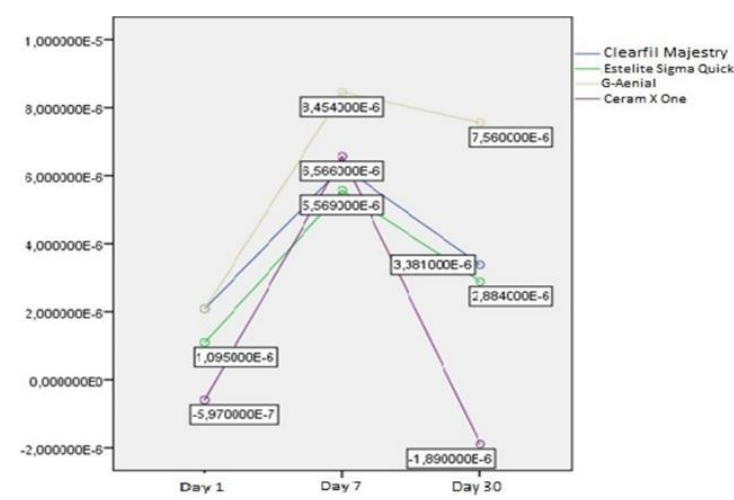

Figure 2. Changes in the water solubility values of the composite resins on Days 1, 7 and 30.

\section{DISCUSSION}

The water absorption and water solublity of composite resins is one of the most important problems affecting the physical, chemical and mechanical properties of composite resins. ${ }^{15}$ Water absorption in restorations causes dimensional changes, fractures in the interface contours and especially discolouration, which leads to a significant degree of aesthetic loss. These negative effects lead to failure of the restoration. ${ }^{14}$

The entry of water molecules into the composite resin occurs in 3 ways. The first is that they penetrate gaps within the material. ${ }^{16}$ The second way is diffusion to the spaces between the inorganic fillers and the third route is that they advance by directly flowing into the regions between the matrix and the fillers in the resin content. ${ }^{12}$ The reason for the movement of water molecules in this study has been reported to originate from the resin matrix and filler structure. ${ }^{17}$

The behaviour of resin-based materials in water shows variations according to the characteristics of the composite. Previous studies have shown that the filler particles, the filler matrix and the bonding agent can change the water absorption values of resin. ${ }^{5}$

Composite resins with a higher filler ratio have lower water absorption. The polymerization time of the composite has a great effect on the water absorption values. ${ }^{18}$ The application of the light for a shorter period than recommended causes inadequate polymerisation, which will have a negative effect on water absorption and solubility. ${ }^{19}$

Another factor which creates a reverse effect on water absorption and solubility is the generation of the composite. Water absorption values vary in resins containing solvents of different amounts. ${ }^{20}$

In addition, factors such as the waiting time of the material in water, surface properties, and the temperature and concentration of the water have an impact on water absorption. ${ }^{14}$

Kalachandra and Wilson ${ }^{6}$ investigated the water absorption values of different composite materials and reported that filling particles and the structure of the bonding agent had an effect on the results.

Zaimoğlu and Sonat's ${ }^{21}$ studies on this subject showed that the change in filler ratios and dimensions of composites had an effect on water absorption and solubility.

As in the current study, evaluations of water absorption and water solubility have been made in accordance with the ISO 4049 standard. ${ }^{22}$ Iwami et al. ${ }^{23}$ have showed that water absorption increases with an increase in weight and solubility creates a reduction in weight in their study.

The most important element affecting water absorption in composite resins is the organic matrix section. Water absorption by the organic matrix, even at a very small amount, has a negative effect on the physical properties of the resin. ${ }^{24}$

Several studies have examined the water absorption of restorative materials. In a study of 4 different composite resins by Palin et al. ${ }^{25}$ the water absorption of Siloron monomer was found to be significantly lower than that of the other resins. The reason that the water absorption results of composite resins are different from each other is due to the 
hydrophobic structure of monomers. In 2013, Boaro et al. ${ }^{26}$ studied water absorption and reported that Siloran and Aelite posterior composites had lower values. In the current study, Ceram X One composite resin was seen to have the lowest water absorption and solubility values.

Water absorption causes swelling of composite resins, and the associated deterioration is irreversible (Powers and Wataha, 2008). ${ }^{27}$ As the particles are finer in hybrid composites compared to microfiller composites, water absorption is lower. Therefore, hybrid compostes have generally been used in studies.

The amount of expansion occurring as a result of water absorption can be measured 15 mins after the start of polymerisation. Most composite resins achieve a balance in the first 7 days (Craig and Powers, 2002). ${ }^{28}$ In our study, there was an increase in water absorption and water solubility values in the first 7 days. Researchers showed that water absorption values of all composites increased with time. ${ }^{29}$ Braden $^{30}$ and Swart $^{31}$ supported this view in their study and stated that water absorption increased from day one to day 30 . In the current study, measurements were taken and recorded at 24 hrs, 7 days and 30 days after polymerisation.

\section{CONCLUSION}

At the end of 30 days, Ceram X One showed the lowest values for water absorption and water solubility. This is due to the matrix and filler structure of the resin. Ceram $\mathrm{X}$ One differs from other materials due to nano ceramic particles and reduced resin content. These properties increase the ability of Ceram $\mathrm{X}$ One composite to be a compatible material.

The biocompatibility of composite resins in clinical use is extremely important. Therefore, it is necessary to eliminate the factors that can negatively affect the physical, mechanical and biological properties of the materials. Water absorption and solubility cause irreversible problems and is therefore a subject which should be carefully examined.

No conflict of interest.

\section{REFERENCES}

1. Kwon Y, Ferracane J, Lee IB. Effect of layering methods, composite type, and flowable liner on the polymerization shrinkage stress of light cured composites. Dent Mater. 2012;28: 801-809.

2. Cangul S, Adiguzel $O$. The latest developments related to composite resins. Int Dent Res 2017;7: 32-41.

3. Antoniadi MH, Papadogianis Y, Kubia EK, Kubias S. Surface hardness of light-cured and self-cured composite resins. J. Prosthel Dent 1991;65: 215-220.

4. Hosoda H, Yamada T, Inokoshi S. SEM and elemental analysis of composite resins. J. Prosthet Dent 1990;64: 669-676.

5. Peutzfeldt A. Resin composites in dentistry: the monomer systems. Eur J. Oral Sci 1997; 105: 97-116.

6. Kalachandra S, Wilson TW. Water sorption and mechanical properties of light-cured proprietary composite tooth restorative materials. Biomaterials 1992;13: 105-109.

7. Mortier E, Gerdolle DA, Jacquot B, Panighi MM. Importance of water sorption and solubility studies for the couple bonding agent - resin-based filling material. Operative Dentistry 2004; 29: 669-676.

8. FerracaneJL. Hygroscopic and hydrolytic effects in dental polymer networks. Dent. Mater 2006;22: 211-222.

9. Toledano M, Osorio R, Osorio E, Fuentes V, Prati C, Garc1 'a-Godoy F. Sorption and solubility of resin-based restorative dental materials. Journal of Dentistry 2003;31: 43-50. 
10. Yap A, Lee CM. Water sorption and solubility of resin-modified polyalkenoate cements. J Oral Rehabil 1997;24: 310-314.

11. Soderholm KJ, Zigan $M$, Ragan $M$, Fischlshweiger W, Bergman M. Hydrolytic degradation of dental composites. J Dent Res 1984;63: 1248-1254.

12. Oysaed H, Ruyter E. Water sorption and filler characteristics of composites for use in posterior teeth. J Dent Res 1986;65: 13151318.

13. Li Y, Swartz ML, Phillips RW, Moore BK, Roberts TA. Effect of filler content and size on properties of composites. J Dent Res 1995;64: 1396-1401.

14. Ortengren $U$, Andersson $F$, Elgh $U$, Terselius B, Karlsson S. Influence of $\mathrm{pH}$ and storage time on the sorption and solubility behaviour of three composite resin materials. J Dent 2001; 29: 35-41.

15. Davis N. A nanotechnology composite. Compend Contin Educ Dent 2003;24: 662-670.

16. Lekatou A, Faidi SE, Ghidasui D, Lyon SB, Newman RC. Effect of water and its activity on transport properties of glass/epoxy particulate composites. Compos., Part A Appl Sci Manuf 1997;28: 223-236.

17. Bektas OO, Eren D, Hurmuzlu F. The evaluation of two composite resins for water sorption. Journal of Cumhuriyet University Faculty of Dentistry 2006;9: 95-100.

18. Bulucu B, Sevilmis HH, Inan U. Different surface finishing procedures' effect on water sorption of composite resins. Journal of Ondokuz Mayis University Dentistry of Faculty. 2004;5: 75-79.

19. Pearson GJ, Longman CM. Water sorption and solubility of resin-based materials following inadequate polymerization by a visible-light curing system. J. of Oral Rehab 1989;16: 57-61.
20. Bastioli C, Romano G, Migliaresi C. Water sorption and mechanical properties of dental composites. Biomaterials 1990;11: 219-223.

21. Zaimoğl11 L, Sonat B. Water absorption and water solubility values of visible radiation cured composite resins. A. U. Faculty of Dentistry Journal 1991;18: 13-7.

22. Indrani DJ, Cook WD, Televantos F, Tyas MJ, Harcowt JK. Fracture toughness of wateraged resin composite restorative materials. Dent Mater 1995;11: 201-207.

23. Iwami Y, Yamamoto H, Sato W, Kawai K, Torii M, Ebisu S. Weight charge of various light-cured restorative materials after water immersion. Oper Dent 1998;23: 132-137.

24. El-Hadary A, Drummond JL. Comparative study of water sorption, solubility and tensile bond strenght of two soft lining materials. J Prosthet Dent 2000;83: 356-361.

25. Palin WM, Flemingn GJ, Burke FJ, Marquis PM, Randall RC. The influence of short and medium term water immersion on the hydrolytic stability of novel low-shrink dental composites. Dent Mater 2005;21: 852863.

26. Boaro LC, Gonçalves F, Guimarães TC, Ferracane JL, Pfeifer CS, Braga RR. Sorption, solubility, shrinkage and mechanical properties of "low-shrinkage" commercial resin composites. Dental Materials 2013;29: 398404.

27. Powers JM, Wataha JC. Properties and Manipulation (Craig) 9(ed). Chapter 4. Mosby, Elsevier Dental Materials 2008: 70-83.

28. Cra1g RG, Powers JM. Restorative Dental Materials 11(ed) Chapter 9. Mosby, St. Louis 2002: 232-24929. Asmussen E, Peutzfeldt A. Influence of UEDMA, BisGMA and TEGDMA on selected mechanical properties of experimental resin composites. Dent Mater 1998;14:51-6. 
30. Braden $M$, Causton BE, Clarke RL. Diffusion of water in composite filling materials. J Dent Res 1976;55: 730-732.

31. Swartz ML, Moore BK. Direct Restorative Resins-A Comparative Study. J Prosthet Dent 1982;47: 163-170.

\section{Corresponding Author}

Suzan Cangül

Dicle University

Faculty Of Dentistry

Department Of Restorative Dentistry

Diyarbakir/TURKEY 21280

Phone : +90 5301902198

$$
\text { +904122411000-3336 }
$$

E-mail : suzanbali@outlook.com 